\title{
TEACHING ABOUT GENOCIDE
}

\section{Colin Tatz}

Researching and writing about genocide is easier than teaching it. An art and a craft, teaching young people and adults about the gruesome and grotesque has particular problems. Generally speaking, while younger audiences may be more inured to virtual violence, older listeners prefer good rather than bad endings.

There are the faltering moments when students cannot handle the material, cry, or rush from the room. This often occurs when viewing "Genocide," episode 20 of the 1974 Thames Television series The World at War. A few are transfixed by the morbidity of it all. This documentary is replete with mass shootings at the rims of pits, bulldozed corpses, and skeletal figures hanging off electrified camp wire. It is meant to shock, and it does. By contrast, Claude Lanzmann's brilliant pastel-coloured marathon documentary, Shoah (1985), sets out to unravel the bizarre and, in its educative way, it is far more compelling and evocative than the shock-horror presentations.

Once under way, students not only engage but become curious, even enthralled by the case studies. They like unravelling what seems so incomprehensible, demystifying what is so surreal. Often there is zest in their studies and assignments, as if on the road to making fresh discoveries about humankind, about good and evil, righteous and not so righteous behaviour, the machinations of bureaucracy, the meanings of accountability and responsibility, the nature of crime and punishment, the politics of apology, the nature and value of reparations, the vexed problem of wilful amnesia and outright denialism, the legacies for the victim communities — and much else as it becomes an intellectual pursuit.

Inevitably, awkward and often unanswerable questions arise. How would I have behaved if conscripted into something like the Hitler Youth? Would I have hidden a family at such danger to myself and my family? Would I have disobeyed an order from above? Could "my kind of people" have performed such deeds? Or if "my people” did do such things, how and why am I different? It is important to convince students of the hypothetical nature of such questions: that this is now, not then, and they are here, not there.

Crucially, audiences learn that genocide is never spontaneous combustion, 
a sudden and totally unexpected eruption into mass violence as seemingly happened in Rwanda in 1994. Every genocide trails history, and each builds up, aggregates, in a succession of "building blocks" or an assembling of "engine parts.” Whichever metaphor one uses, genocide is evolutionary, not revolutionary. A holistic approach is needed, one that embraces anthropology, biology, cultural studies, geography, history, law, philosophy, sociology, studies of religion, and more. Most teenagers are not conversant or comfortable with that combination of concepts and the vocabularies involved. A different kind of educative process is required that involves teaching students how to confront some very large canvasses.

Some teachers use what I call the science-fiction movie approach-a group of bad guys descended from an alien spaceship in 1933, wrought evil upon the world and were then vanquished forever by the allied good guys a dozen years later. What is sometimes called "slice-history" does not work for the Holocaust or for any genocide. In the former case, it leads to ideas about a totally new kind of event, something meta-historical or even meta-physical. The Holocaust was many things: it is the central case in teaching, the tremendum of modern times certainly, but always a genocide and therefore examinable in the historical context of genocides.

What is regrettable is the lasting influence of American psychologist Gordon Allport who, in 1954, wrote The Nature of Prejudice. He posited a syndrome, something directly connected, running together, and sequential:

1. Antilocution — bad-mouthing an ethnicity, a race, a people;

2. Then the social exclusion of such people;

3. Followed by physical attacks on the target groups, such as lynching, desecration of tombstones;

4. Next, geographic exclusion of the targeted group from neighbourhoods, regions, nations;

5. Finally, their proposed, attempted or actual extermination.

American scholar Gregory Stanton has outlined 10 sequential stages of genocide, and Winton Higgins and I have established a similar set of demonstrable, connected steps - from formulation of the very idea to its actual implementation and aftermath. ${ }^{1}$ Yet the Allport "syndrome" was, and remains, historical and empirical nonsense. These actions assuredly exist, but there is not any science of syndrome, no sequence of indelible connectedness. Most societies have had salon and literary antilocutions and yet have neither physically at-

1 Colin Tatz and Winton Higgins, The Magnitude of Genocide (Santa Barbara: Praeger, 2016), 112-13. 
tacked Jews, nor killed them. Jews have been socially and geographically excluded from clubs, suburbs, schools and universities, yet not only survived, but thrived. Many communities, including Jews in Australia, have had tombstones shattered and synagogues set on fire without ensuing trade boycotts, bannings from the public service, roundups, deportations and gassings. The seemingly unshakeable problem is that so many believe "it has to start somewhere" - in the manner of Allport's antilocution—and point to either radio shock jock language, The Merchant of Venice, Oliver Twist, or to golf club exclusions. They are not the passageways to genocide, and that is not the way to teach about genocide.

Let me share some personal thoughts about teaching (and thinking) about genocide, developed over the past 30 years. My approach is not that of an instruction manual, nor is it set in stone, but it has worked for my audiences over the years, and for a number of former students who in turn have become teachers of the subject.

Here I address some of the approaches that work well in unravelling the "crime of crimes," among others, the value of a broad and holistic opening, a need to distinguish genocide from related crimes, the essential focus on the Holocaust, the ways of coming to grips with the actors involved in the phenomenon, and the ingredients common to most genocides.

\section{The overview}

Whatever it was called before Raphael Lemkin gave us the word genocide in 1944, there was, all too commonly, attempted or actual extermination of peoples in classical antiquity (roughly $800 \mathrm{BCE}$ to $500 \mathrm{CE}$ ), the middle ages (500 to late $1500 \mathrm{CE}$ ), and the modern era (1600 to the present). Genocide is not simply a twentieth century horror story: there is a magnitude to genocide in and across world history. ${ }^{2}$ The twentieth century warrants especial attention, but for maximum effect students need to approach genocide from the events in German South-West Africa [now Namibia] in 1904-1906, through to the Ottoman Turk genocides of Armenians, Assyrians and Greeks from 1915 to 1923, through to the Holocaust era starting in 1933. Then separately, traverse the dozens of genocidal episodes since the placard in the Buchenwald camp proclaimed (in 1945) the now empty catchcry of "Never Again.” These should include Bangladesh, Burundi,

2 See Mark Levene, Genocide in the Age of the Nation State (London: I.B. Taurus, 2005); Ben Kiernan, Blood and Soil: A World History of Genocide and Extermination from Sparta to Darfur (New Haven: Yale University Press, 2007); Tatz and Higgins, The Magnitude. 
Cambodia, Darfur, Guatemala, Bosnia, Kosovo, Rwanda, Chechnya, East Timor, Liberia, Sri Lanka, the Democratic Republic of Congo and the current genocidal jihadism of ISIS.

\section{Gradations of genocide}

Not all cases of genocide are alike, let alone the same. We need a measuring rod-and that can only come from explaining that the only judiciable and actionable instrument we have is the 1948 United Nations Convention on the Prevention and Punishment of the Crime of Genocide ("the Genocide Convention"), flawed as it is. There is no point going over the many definitions, even the improved ones that have come from scholars since 1948. The Genocide Convention sets out five somewhat divergent acts that constitute the crime of genocide, ranging from Article II (a) the physical killing of people because they are those people, to Article II (e) forcibly removing their children from their group to another group membership. And it relates to only four categories of people: racial, ethnic, religious, or national. Therein lies a problem in teaching about genocide: there are five essentially differing actions defined, with rape now added by the courts as a genocidal act. In spite of clear-cut differences, the five are co-equated and each can be ruled genocide. The equating of child removal, a form of social and cultural death, with physical death, presents a problem for many. Each is heinous but the Convention allows no gradations between them. That is how international law defines it and that is what we will have to abide by for many years to come. ${ }^{3}$

We need a metaphorical way of measuring, or at least appreciating the intensity and the gradations of genocidal events. Inevitably, there are differences in intent, motive, time-frame, scale, methods used, rescue and intervention efforts, outcomes, impacts on victim groups, legacies, trials and accountability, apologies, reparations, levels of denial, memorialisation, and so on. (Sometimes a nasty element intrudes: "my genocide" was bigger than or superior to yours-a league table of horror, what historian Michael Berenbaum excoriated as "a calculus of calamity" or a "suffering Olympics".) $)^{4}$ In Rwanda in 1994, 800,000 people were killed in 100 days. In Australia, physical murder of Aboriginal people and child removal spanned almost 124 years, with killings in

3 The statute of the International Criminal Court in 2002 adopted verbatim the Genocide Convention definition.

4 Michael Berenbaum, A Mosaic of Victims: Non-Jews Persecuted and Murdered by the Nazis (New York: New York University Press, 1990). 
sporadic "hunting party" attacks over weekends accounting for some 30,000 to 50,000 people, and child removal starting in late 1839 and ending in the late 1980s, involving perhaps 30,000 children. ${ }^{5}$ Very different experiences, yet both were cases of genocide.

\section{A hierarchy of crimes}

Confusion often arises between genocide, genocidal massacres, massacres, pogroms, atrocities, war crimes, crimes against humanity and crimes against peace. There is no shortage of case studies to help illustrate the distinctions between them. Audiences are helped by examining events as seemingly remote as the Chmielniki massacre of Jews in the Polish- Lithuanian Commonwealth (now Ukraine) in 1648. Some 100,000 Jews perished in this Cossack rebellion, but the aims were political against the ruling regime rather than the intended elimination of most or all Jews. The scale of the events make it more of a genocidal massacre. The term for such events is the Yiddish word pogrom—an orchestrated attack on people and property as a warning, reprisal, or a chance for booty. (There was, and is, a homicidal tenor to pogroms, hence the adjective "genocidal".) What Lieutenant William Calley did at the village of My Lai in Vietnam in March 1968 was an atrocity and a massacre (of some 500 men, women and children), not an action to eliminate all Vietnamese. What the Nazis did to Jews in Poland was genocide, the extirpation of both a people and the very idea of such a people; what it did to Poland was a series of war crimes not to eliminate Poles but to dismantle the political entity of the Polish state, and enslave the inferior Slavic peoples. ${ }^{6}$

Unlike the allied behaviours mentioned above, genocide is a specific crime comprising the five acts specified in the Genocide Convention. The specificity of the crime is important because of a popular penchant of people to reach for the word "genocide" whenever they want to attract attention to a particularly heinous event.

\section{The actors}

Holocaust teachers most often use a triangle to portray the actors and factors involved in that crime: the perpetrators (on top), the victims, and the bystanders whose indifference or acquiescence allows the actions to unfold,

5 Colin Tatz, Genocide in Australia: By Accident or Design? (Melbourne: Monash Indigenous Centre and Castan Centre for Human Rights Law, 2011).

6 For a discussion of definitions, see Tatz and Higgins, The Magnitude, chap. 2. 
unhindered. I use a hexagon, sometimes a heptagon, including perpetrators, victims, bystanders, beneficiaries, rescuers, denialists, and (on not too many occasions) the punishers. These are the common actors in modern genocidal events, each needing analysis and discussion.

The beneficiaries are little discussed and it is worth taking students through some examples of profitable "neutrality" during World War Two-as with Sweden, Switzerland and Spain. Sweden supplied Germany with steel and machinery for war; Switzerland provided war materials and acted as a banker for Jewish assets looted by the Nazis; Spain contributed thousands of men to the Nazi military and supplied rare minerals to Germany.

The rescuers include not only individuals designated as the Righteous Among the Nations, but organisations like the Polish Catholic Zegota (Council for Aid to Jews), whole towns like Le Chambon in France and Niewiande in Holland, and such nation-states as Bulgaria and even Italy in World War Two. They contrast sharply with those nations that did nothing, refused to do anything, averted their eyes, or chose (and choose now) to ignore genocide as it was (or is) occurring for fear of having to become involved.

However small rescue looms in genocide history, it is important for audiences to have a glimmer of optimism to offset the blackness and nihilism. Rescue is a form of intervention and students need introduction to the few efforts to intervene physically to stop a genocide. Declaring a nofly zone (NFZ) in 1991-1992 to stop Saddam Hussein dropping chemical weapons on Kurds in northern Iraq, and later, similar NFZs in Bosnia and Libya, are among the few examples. A distinction must be made between intervention and prevention. We have yet to see a successful attempt to prevent what is a clearly foreseeable genocide, such as in the Nuba Hills region of Sudan today.

\section{Accessing the actors}

How do we get to these participants, these actors? Even with libraries of scholarly books, journals, as well as internet materials, the most effective teaching is to have students examine original material such as documents, archival materials, newsreel films, documentaries; and either to listen to a survivor or read what would have been contemporary eyewitness accounts. Post-event memories and memoirs are valuable but are at times corrupted by memory loss, appropriation of other testimonies and historical accounts, and by sheer time.

Holocaust documents are a start. They do not tell the whole story, but sufficient thereof. The Documents of the Holocaust is a good volume from which to 
work. ${ }^{7}$ Students may find it easier to get to grips with actors from a somewhat surreal collection by historian Raul Hilberg, titled Documents of Destruction. ${ }^{8}$ They can pick a short document for analysis: for example, an order placed from Poland to Berlin for so many pounds of bread and marmalade to induce Warsaw ghetto dwellers to "volunteer" for deportation; another for a huge quantity of nuts, bolts and tools (for gas chambers); another showing a railway timetable with loaded trains going to a destination (Auschwitz) and coming back empty and needing to be cleaned (having been paid for by the Jews).

Most local Holocaust museums will have documents or facsimiles on display or in their archives. Accessing material online is now possible from institutions like Yad Vashem in Jerusalem, the US Holocaust Memorial Museum in Washington, the Imperial War Museum in London, and the massive resources held at Bad Arolsen in Germany. The Armenian Genocide MuseumInstitute in Yerevan is fast developing into a key resource. The Tuol Sleng Genocide Museum in Cambodia's Phnom Penh has become a "must” on visits there and provides internet material. Australia's National Archive in Canberra holds important material on the Aboriginal Stolen Generations.

Transcripts of trials and judgments by courts are an excellent resource. There is nothing quite like the spotlight of a forensic arena, under tight rules of evidence, to provide insight into an event and the dramatis personae. The Myall Creek Massacre in New South Wales in 1838, and the subsequent trials and executions of those who had killed local Aboriginal people, tell us a great deal about frontier society. ${ }^{9}$ Trials of Nazis, Serbians, Rwandans teach us that "something happened" and what the something was-they are more than simply about crime and punishment. The Nuremberg trials, the doctors' trials and that of the Einsatzgruppen tell their own terrifying tales. An important trial in more recent times was the Akayesu case in Rwanda. ${ }^{10}$ The International Criminal Tribunal for Rwanda (ICTR) established that direct and overt evidence is not always needed to establish that something happened and that someone was guilty: the context, preceding and surrounding history and circumstances can as readily establish that genocide was not only intended but occurred.

Valuable lessons lie in looking at statutes, decrees, and regulations. Again, the Holocaust era provides numerous examples of the Nazi rush to legislation

\footnotetext{
7 Yitzhak Arad, Yisrael Gutman and Abraham Margoliot, eds., The Documents of the Holocaust: Selected Sources on the Destruction of the Jews of Germany and Austria, Poland and the Soviet Union (Jerusalem: Yad Vashem, with the Anti-Defamation League and Ktav Publishing House, 1981).

8 Raul Hilberg, Documents of Destruction: Germany and Jewry, 1933-1945 (Chicago: Quadrangle Books, 1971).

9 The Myall Creek Memorial Site was unveiled in 2000. It is vandalised regularly.

10 The Prosecutor v. Jean-Paul Akayesu (1998) ICTR-96-4-T (Aust.).
} 
immediately after coming to power in 1933 . There are several Ottoman statutes that legalised and legitimated deportations and confiscation of Armenian property before the genocide began in 1915. Going to original sources enables students to start thinking for themselves rather than being told what to conclude from scholarly commentaries.

Finding a genocide survivor may be difficult. Ageing and diminished memory do not detract from the excruciating experiences that unfold, but their sense of general history is not always accurate. Eyewitness accounts are now becoming common. (Social media technology provides images of events as they happen.) Samuel Totten's numerous volumes provide critical essays, guides to the literature, and some startling witness accounts recorded at the time. ${ }^{11}$

Film attracts attention. Segments of Lanzmann's compelling and memorable Shoah documentary convey the genocidal process without once resorting to footage of killing or camp liberation. Part two of the 2007 series Racism in History is "The Fatal Impact" and is essential viewing. The best and most lurid of Nazi propaganda films is Der Ewige Jude (The Eternal Jew), a 1940 "masterpiece" of new film techniques and crudities. The 2010 documentary Einsatzgruppen: The Death Brigades brings the viewer as close as one can get to "the action."

A vexing question arises when it comes to fiction, poetry, theatre, painting and movies depicting genocide. Apart from the art versus reality debate, the question is whether these art forms capture the reality of the time and achieve impact on those who were not there. Even a movie like Schindler's List (1993) insists on a redemptive (happy or "happier") ending. The Kramer Nuremberg film, mentioned below, is a more accurate account, and more dramatic for its sense of authenticity. László Nemes' 2015 movie, Son of Saul, depicting a day-and-a-half in the lives of the Sonderkommando, the Jewish prisoners in Auschwitz forced to dispose of the corpses, is considered one of the best films of all time.

\section{The professions}

The popular image of genocide is of a despotic regime in which the ruler orders "mechanics," the "field" thugs and guards, to go about the business of punishing, pillaging, killing. Imagery lingers of hard-core prisoners in Turkey, usually murderous Circassians, released on condition they kill Armenians on

11 See, among others, Samuel Totten and Robert K. Hitchcock, eds., Genocide of Indigenous Peoples: A Critical Bibliographic Review (New Brunswick, NJ: Transaction Publishers, 2011). 
death marches, and of Brown Shirts (the SA) in Germany cutting off rabbinical beards and burning books, seemingly at random and self-motivated.

The planning and specificity of gathering targeted populations, of relocations to labour camps, concentration camps, or death factories, required bureaucratic efficiency. Most of that came from the professions: architecture, accountancy, biology, chemistry, education, engineering, law, medicine, pharmacy, physics and zoology. Students are fascinated by this phenomenon and disbelief soon enough becomes acceptance as they tackle projects such as genocide and the law, medical ethics in the shadows of the Holocaust, and so on. A riveting text for them is Stanley Kramer's 1961 masterly Judgment at Nuremberg, based on Abby Mann's scripted account of the last of the Nuremberg trials, that of Nazi judges.

Books on the professions are not that plentiful, but Max Weinreich's classic Hitler's Professors, ${ }^{12}$ written in 1946, and another immediate post-war account by Alexander Mitscherlich and Fred Mielke, The Death Doctors, ${ }^{13}$ are crucial. Richard Grunberger's 1971 Social History of the Third Reich examines the rush to join the Nazi movement by doctors and teachers in particular. ${ }^{14}$ In the 1990s, Konrad Jarausch probed the legal, educational and engineering professions. ${ }^{15}$ Even the seemingly innocuous profession of accountancy was heavily involved in keeping the ledgers of genocide. ${ }^{16}$

\section{The centrality of the Holocaust}

Holocaust studies overwhelm-in canvas, breadth, depth, scope, meticulous detail. For any other single case study, there are at least a thousand Holocaust items. The templates are there, the analytical tools are there, the over-researched and the under-researched matters are there, the atlases, encyclopaedias, bibliographies are all there as models and paradigms. The trailer or prequel of the Armenian Genocide is there and needs to be taught in its own right of course, but also because of the precedent and prelude it set for the Holocaust: the deportations and "relocations" of population, confiscation of property, rounding-up of men for slave labour and death, medical experiments

\footnotetext{
12 Max Weinreich, Hitler's Professors: The Part of Scholarship in Germany's Crimes Against the Jewish People (1946; New Haven: Yale University Press, 2005).

13 Alexander Mitscherlich and Fred Mielke, The Death Doctors (1949; London: Elek Books, 1962).

14 Richard Grunberger, A Social History of the Third Reich (1971; London: Phoenix, 2005).

15 Konrad Jarausch, The Unfree Professions: German Lawyers, Teachers, and Engineers 1900-1950 (New York: Oxford University Press, 1990).

16 Edwin Black, IBM and the Holocaust: The Strategic Alliance between Nazi Germany and America's Most Powerful Corporation (London: Little, Brown and Company, 2001).
} 
in hospitals, elementary gas chambers and the final death marches into Syria. The Nazi regime learned much from the Young Turks. As Stefan Ihrig has reminded us, Kemal Atatürk loomed large in the Nazi imagination. ${ }^{17}$

Some genocide scholars seem to want to bypass the Holocaust, to engage in a chosen case study strictly avoiding not just the substance of the Holocaust but its echoes, shadows, metaphors and analogies. Hardly professional or academic, it is an approach unbecoming of scholarship. As noted above, the templates and frameworks of analysis by eminent and acclaimed scholars over the past 70 years are ever-present. Some scholars assert that the Holocaust drowns or eclipses other cases: it may well do so, but the established and tested templates are unassailable and cannot be swept aside merely in pursuit of "new" lenses. The Holocaust perspectives have yet to be found wanting or inappropriate.

\section{Genocide and language}

Inevitably, there is a flipside to these documented instructions and actions: the unstated, unspoken orders to round up, deport, loot, kill. In many cases, genocidaires invent new language, as with the Nazi euphemisms. ${ }^{18}$ Resettlement, special treatment, and relocation "solutions" are but masks for the killing fields and methods of death. Part and parcel of this attempt to hide reality is the dehumanisation, animalisation and insectification of victims as bacilli, viruses (Jews), pests and vermin (Roma), cockroaches (Tutsi). Rowan Savage has analysed the language of dehumanisation: the sub-humans, fauna, wild beasts, vermin, rodents, insects, birds, pigs, monkeys, snakes. ${ }^{19}$

Not all genocides are acts of commission: at times, genocide is an act of omission, a deliberate failure to feed and water people for example. Again, there are degrees and gradations of criminal intent, or gross negligence involved-as in Ukraine in the 1920s and 1930s, the deliberately low rations for Jews in the Nazi era, some less than ambiguous agrarian practices in China, Ethiopia and North Korea in more recent times.

17 Stefan Ihrig, Atatürk in the Nazi Imagination (Cambridge, MA: Belknap, 2014). His new book, Justifying Genocide looks at the connections between both cases more comprehensively.

18 Shaul Esch, "Words and Meanings: Twenty-Five Examples of Nazi Idiom," Yad Vashem Studies 5 (1963), 133-67.

19 Rowan Savage, “ 'Vermin to be Cleared Off the Face of the Earth': Perpetrator Representations of Genocide Victims as Animals,” Genocide Perspectives III: Essays on the Holocaust and Other Genocides, eds. Colin Tatz, Peter Arnold and Sandra Tatz (Blackheath, NSW: Brandl \& Schlesinger, 2006), 17-53. 


\section{Disciplinary approaches}

The most appropriate discipline for teaching genocide is history. There is now strong attention from sociology, political science, law and more recently, anthropology, philosophy, and two somewhat fuzzy subsets labelled human rights and, increasingly, peace and conflict studies. "Human rights" is a term now (fashionably) attached to studies of atrocities, mass death, and genocide. It is an amalgam of many things: philosophical, religious, ethical, moral, legal. The problem is not that particular admixture but the haphazard way in which it is used as a mantra to cover a multitude of behaviours that co-equate issues like poverty, poor education, exclusion from voting, ill health and life's inequities with purposeful killings in Rwanda, Bosnia and Cambodia. The spectrum becomes so broad as to be meaningless.

Rarely used is political geography. It is highly effective, especially with the use of computer-generated maps. Thus, one can present a political map of Africa in 1939 and then another of that continent by 1970. In 30 short years, boundaries changed, new states emerged, and long-term colonial regimes that were there have vanished. Some 30 genocidal events have occurred in Africa as a result of colonial practices, and even more calamitous outcomes from ill-considered decolonisation procedures. Or, one can show graphically and demographically that Europe had 10 million Jews in 1939 and less than 2 million 50 years later-and ask how and why?

Ethnic cleansing-so historian Norman Naimark tells us $^{20}$-inevitably bleeds into genocide. This is well illustrated by the cases of the Greeks, Assyrians and Armenians in Turkey, the Soviet deportations of Chechens, Ingush and Crimean Tatars, and the more recent Wars of Yugoslav Succession. The present-day crises in Afghanistan, Iraq, Yemen and Syria, and the plight of Kurdish peoples generally, lend themselves to the lens of political geography.

\section{The race factor}

Unfortunately, racism is the only single, flat word we have to cover a multitude of attitudes and actions. Since earliest history distinctions have been made between "them" and "us" on the basis of tribal affiliation, kin membership, skin colour, body form, ethnicity, religion, material culture, custom, language, and geographic domain. Race-ism has to cover all such different attitudes and actions. Essentially, racism refers to real (or imagined) beliefs that a specific characteristic, such as colour, language or religious belief, gives rise to cer-

20 Norman Naimark, Fires of Hatred: Ethnic Cleansing in Twentieth-Century Europe (Cambridge, MA: Harvard University Press, 2001). 
tain undesirable social characteristics — and one can therefore legitimately take action against such a target group. Thus, in shorthand, blacks were slaves because they were black, or corporeal Jews were invisible and dangerous viruses to be eradicated.

Rare indeed is the genocide in history where race, in this sense, has not been a key factor. Much of the Atlantic slave trade led to the destruction of African and Caribbean family and ethnic life. Racism underlay the fate of Nama and Herero peoples in South-West Africa, the Congo Free State, and Native Americans. Similarly, the linguistically and religiously different Armenians in Turkey; the Bengali-speakers of East Pakistan; the Christian tribes of Darfur; the Chinese in Nanking at the hands of the Japanese; the Jews; the Tutsi in Rwanda; the Vietnamese and Muslim Cham in Cambodia; Bosniaks in the former Yugoslavia. And so many more.

\section{The "science" factor}

Appreciating the race factor also requires going through the growth of "scientistic racism," that is, the works of anatomists and physical anthropologists who began to examine and compare the human form and then started to attribute social characteristics to the physical ones. When physical forms as such could not establish a "suitable" hierarchy of races, they turned to measurements of "intelligence," using craniology (skull measurement) as the ultimate criterion. Researchers concluded that Caucasians-named after what was thought to be the perfect ("white") skull found in the Caucasus mountains in Russia-had the largest brain casing (87 cubic inches), according to physician Samuel Morton in his Crania Americana (1839). Native Americans had a mean volume of 82 cubic inches (measured using mustard seed) that, Morton deduced, made them slow of thought, averse to agriculture, vengeful, and lovers of warfare. Ethiopian and black skulls held an even smaller quantity of seed (78 cubic inches) but their owners' bodies were the more muscular. Thus laboratories spawned the brain versus brawn (or white versus black) dichotomy that is still prevalent in many circles. Australia's Indigenous people (“Australoids") had less skull volume than any other people, and were ascribed as having even more reduced capacities - a furphy propagated in Australian school texts until the 1980s.

Craniology, sometimes called craniometry, fell from favour at the turn of the twentieth century. That scientific nonsense gave way to another form of "brain power," the Stanford-Binet test of intelligence, the modern IQ test, still in use, or misuse, today for streaming children into different levels of education, for separating classes of people, the bright from the simple, and so on. 
(No matter what spin one puts on modern IQ testing, it remains of the same genre and "scientific" validity as skull measuring.) ${ }^{21}$

Hand in hand with these developments was the emergence of eugenics, a veterinary term, a "science” that intended turning society into a social laboratory in which nations and "races" could be regulated biologically to produce desired citizens and breed out or otherwise exclude undesirable ones, like Roma (even as this is being written). Eugenics was hardly a Nazi fantasy. The United States had powerful elements that wanted nothing more than a white, Protestant America - to the detriment and, preferably, the exclusion of all who did not fit: Blacks, Catholics, Jews, Hispanics. ${ }^{22}$

There was another significant point about eugenics and "racial hygiene." Rulers no longer had to rely on religious canon to justify superior over inferior, slavery, "the white man's burden," imperial destiny and the like; science, with men in white lab coats and academic gowns, could now "prove" the fitness of the fittest to rule.

\section{The governance factor}

Two eminent scholars-Yehuda Bauer in Israel and Richard Dekmejian in the United States-have listed what they see as the prerequisites of twentieth century genocide: an ancient hatred or similar ideological imperative; a brutal dictatorship; a war setting; a compliant bureaucracy; and a use of some form of technology. ${ }^{23}$ That template may well fit the Armenian and Jewish experiences, but it does not have universal application. Some genocides have occurred in (international) peacetime. But the main issue to convey to students is that genocide is not the sole domain of brutal dictatorships. Democracies are as capable of genocide in their way. One can point to Wilhelmine Germany at the start of the twentieth century, to Belgium in the Congo's history and that of both Burundi and Rwanda, to French behaviour in territories like Algeria, to some dubious British behaviour in the Empire's heyday, to Canada, the United States, and Australia in their frontier and later eras.

Following the Genocide Convention, one has to look at child removal practices in Canada and the United States, with children taken from families and sent to compulsory residential boarding schools for up to 12 years, denied va-

21 Leon Kamin, The Science and Politics of I.Q. (London: Penguin Books, 1974).

22 See Stephen Jay Gould, The Mismeasure of Man (New York: Norton, 1981); Leila Zenderland, Measuring Minds: Henry Herbert Goddard and the Origins of American Intelligence Testing (Cambridge, UK: Cambridge University Press, 2001).

23 Tatz and Higgins, The Magnitude, chap. 4. 
cation time with kin, in the hope that their "Indian-ness" would be eradicated at the end of that time.

A much starker case of "decent democrats" committing the crime is Australia, with both a physical killing era and, later, massive and wholesale child removal practices. Under a Westminster system of constitutional governance, with reverence for the rule of law, with claims about a remarkable record of according and affording human rights, contrived-from 1896 to approximately 1985 (in Queensland) — to have Aboriginal people live under separate and special statutes that granted not one right in the amalgam we call human rights. They were "citizens" but could not enter or leave a reserve without permission, could not sell their labour on the open market, earn the national basic wage, marry non-Indigenous people without permission, have sex across the colour line, vote, drink, go within stipulated distances of licensed premises, carry firearms, join trade unions, own land or property, make wills, have legal guardianship of their children, apply for passports, or give evidence on oath in court. In several jurisdictions, they could be jailed by local administrators and missionaries (quite outside the domain of the national criminal justice system) for offences that only they could commit, like playing cards, being cheeky, being idle, refusing to work, or committing adultery. ${ }^{24}$

\section{Dealing with denialism}

People have difficulty dealing with denialism, especially of the Armenian and Jewish events. Students (and lay people) need to learn that the onus is not on them to prove that certain things happened, but that the burden lies on the denialist to show that they did not happen. For example: give the students a copy of the SS Statistics on the "Final Solution of the Jewish Question" March 23, $1943 .^{25}$ Let them confront a denialist and insist on being shown how and in what way that document was a forgery, who did the forging, on what paper and with what inks and typewriters and official stamps. Students need to appreciate that denialists never offer proof but simply assert; and that these are not debatable issues on which there are alternative views. Turkish denialism is much harder to deal with, given that the whole apparatus of the Republic of Turkey dedicates itself to denying the events of 1915 to 1923 . Nevertheless, students need to know that some 23 nation states have recognised that genocide, as have some 48 American states, two Australian parliaments, the European Parliament, the Council of Europe, and the Vatican, among others. The onus is on 
the denialists to show why it is that there has been such widespread "conspiracy” among reputable people and organisations to besmirch Turkish honour.

\section{Conclusion}

The social sciences engage in advocacies, with differing and even antithetical viewpoints. Genocide is unique: there cannot be a (legitimate) "pro-genocide” stance and there can be no alternative point of view as to its "merits." It is rare indeed to have a subject that does not have another "side"-except perhaps in today's upside-down world of ISIS and its confident claims that the killing of all infidels worldwide is warranted, no, commanded by the Quran.

There have been some lame attempts at justification of genocidal practices, notably the North American system of compulsory residential boarding schools, and Australia's forcible removal of children, both claiming this was "in their best interests." While the Genocide Convention conveys, from its 1948 context, that "with intent to destroy" meant to destroy with malice and male fides, there is no definition (or court interpretation) of the nature of "intent." Arguing that the intent was "good" is to trivialise and relativise the action. Australian philosopher Raimond Gaita has pinned down the matter: "the concept of good intention cannot be relativised indefinitely to an agent's perception of it as good.” If we could, Gaita writes, then we must say that Nazi murderers had good, but radically benighted intentions, because most of them believed they had a sacred duty to the world to rid the planet of the race that polluted it. ${ }^{26}$

We have a sense of universalism about genocide, its perpetrators, its nature, horrors, outcomes, and legacies. The conundrum remains: why then do so many nations, governments, institutions and agencies look the other way, pretend it is not happening, ponder or dither over intervention when prevention and pre-emptive action was well warranted? There is no shortage of signposts, of some obvious "at-risk" factors when one examines - as intelligence agencies undoubtedly do daily-gross poverty, scarcity of resources, historical animosities, geographic and geopolitical conflicts, internecine and religious wars, territorial claims, and a sequential set of circumstances clearly suggesting prior or imminent attacks on targeted groups. Indifference is said to be a major, if not the major factor in genocide-that without the indifferent bystanders the event cannot take place.

Yehuda Bauer teaches that there is often an adjective involved: hostile in-

26 Raimond Gaita, “Genocide and Pedantry,” Quadrant, July-August 1997, 41-45; Raimond Gaita, “Genocide: The Holocaust and the Aborigines,” Quadrant, November 1997, 17-22. 
difference. A tautology on the face of it, nevertheless there is a real sense in which averting the eyes is more than just "not wanting to be involved": it emanates a sense of not considering the victims as worthy people.

Many years ago, when Elie Wiesel- survivor of Auschwitz and Nobel Laureate for Literature-was asked about what anyone could do about the Holocaust, he replied that one must teach, and teach again. Teaching, of course, will not prevent genocide, but it will lay bare the essences of that behaviour. And so my contribution is to teach and to talk, even to preach. 